\title{
"Transition to a new economy: transformation trends in the field of income and salary functions"
}

\begin{tabular}{|c|c|}
\hline AUTHORS & $\begin{array}{l}\text { Olena Grishnova (D https://orcid.org/0000-0002-4178-1662 } \\
\mathbb{R} \text { http://www.researcherid.com/rid/G-1740-2017 } \\
\text { Andriy Cherkasov (D https://orcid.org/0000-0002-3653-2709 } \\
\mathbb{R} \text { https://publons.com/researcher/1808547/andrii-v-cherkasov/ } \\
\text { Olena Brintseva (D https://orcid.org/0000-0003-2442-3000 } \\
\text { R http://www.researcherid.com/rid/G-2045-2017 }\end{array}$ \\
\hline ARTICLE INFO & $\begin{array}{l}\text { Olena Grishnova, Andriy Cherkasov and Olena Brintseva (2019). Transition to a } \\
\text { new economy: transformation trends in the field of income and salary functions. } \\
\text { Problems and Perspectives in Management, 17(2), 18-31. } \\
\text { doi:10.21511/ppm.17(2).2019.02 }\end{array}$ \\
\hline DOI & http://dx.doi.org/10.21511/ppm.17(2).2019.02 \\
\hline RELEASED ON & Thursday, 18 April 2019 \\
\hline RECEIVED ON & Monday, 29 October 2018 \\
\hline ACCEPTED ON & Monday, 25 March 2019 \\
\hline LICENSE & $\begin{array}{l}(c) \text { EY } \\
\text { This work is licensed under a Creative Commons Attribution } 4.0 \text { International } \\
\text { License }\end{array}$ \\
\hline JOURNAL & "Problems and Perspectives in Management" \\
\hline ISSN PRINT & $1727-7051$ \\
\hline ISSN ONLINE & $1810-5467$ \\
\hline PUBLISHER & LLC "Consulting Publishing Company "Business Perspectives" \\
\hline FOUNDER & LLC "Consulting Publishing Company "Business Perspectives" \\
\hline
\end{tabular}

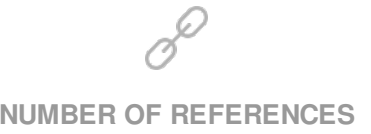

44

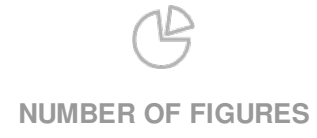

0
NUMBER OF TABLES

4

(C) The author(s) 2023. This publication is an open access article. 


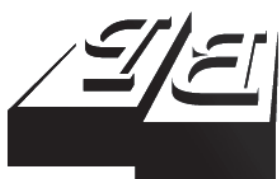

BUSINESS PERSPECTIVES

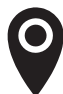

LLC "CPC "Business Perspectives" Hryhorii Skovoroda lane, 10, Sumy, 40022, Ukraine

www.businessperspectives.org

Received on: $29^{\text {th }}$ of October, 2018 Accepted on: 25 th of March, 2019

(C) Olena Grishnova, Andriy Cherkasov, Olena Brintseva, 2019

Olena Grishnova, Doctor of Economics, Professor at the Department of Economics of the Enterprise, Taras Shevchenko National University of Kyiv, Ukraine.

Andriy Cherkasov, Doctor of Economics, Associate Professor, Head of the Personnel Management and Labor Economics Department, Ukrainian State Employment Service Training Institute, Ukraine.

Olena Brintseva, Ph.D. in Economics, Associate Professor, Personnel Management and Labor Economics Department, Kyiv National Economic University named after Vadym Hetman, Ukraine.

\section{(ㄷ)(i)}

This is an Open Access article, distributed under the terms of the Creative Commons Attribution 4.0 International license, which permits unrestricted re-use, distribution, and reproduction in any medium, provided the original work is properly cited.

Olena Grishnova (Ukraine), Andriy Cherkasov (Ukraine),

Olena Brintseva (Ukraine)

\title{
TRANSITION TO A NEW
} ECONOMY: TRANSFORMATION TRENDS IN THE FIELD OF INCOME AND SALARY FUNCTIONS

\begin{abstract}
The rapid spread of information technologies and other phenomena in the new economy causes significant changes in the social and employment spheres. The objective is mainly to analyze and systematize the peculiarities of labor and payment for it in the new economy. In this paper, the analytical grouping method for characterizing salary functions, as well as changes in the social and labor sphere that take place in the new economy, correlation-regression analysis to determine the relationship between average income and factors affecting its level are used. The results of the paper show three important findings. Firstly, the gradual changes in the content of labor and forms of its organization that happen in modern conditions under the influence of dissemination of information and communication technologies require new approaches to income adjustment, management of employment of the population, development of professional education system. Secondly, the authors also found that the fair employee compensation, ensuring productive employment in modern conditions, is a challenge not only of the national, but also of international scale. Thirdly, the prospective directions of reducing inequality and social tension in society are the guarantee of the basic unconditional income, progressive tax on all types of income, reduction of the length of working time while maintaining payments and improving productivity. In addition to avoiding social dangers, it would be a proactive progressive function of expanding human development opportunities.
\end{abstract}

\section{Keywords}

\section{JEL Classification}

\section{INTRODUCTION}

The rapid dissemination of information technologies and other phenomena in the new economy causes significant changes in the social and employment spheres. The noted events are primarily related to the changes in the content of work and forms of its organization, the emergence of new professions, in particular in the IT field, extensive development of high-technology sectors of the economy, the expansion of opportunities for the formation and use of human capital, an increase in the options of human choice, and the emergence of new risks. Gradual changes in the content of work and its organization forms also result in the transformation of the integrity and functions of remuneration. New criteria for assessing the personal labor input of employees lead to changes in compensation, forming different, rather diversified sources of income. A modern employee with the help of information and communication technologies can simultaneously participate in many projects. In the new economy, the diversity and flexibility of the employment conditions increase, an employee can enter into individual contracts. Furthermore, in the new condi- 
tions, the employee has the highest degree of freedom and independence, professional networks of specialists and freelancers are becoming widespread, and the decentralization of business processes and management increases. However, changes in the social and employment sector, inherent in a new economy, can also result in a decrease of employment stability, less social guarantees for employees, an increase in the inequality of compensations and incomes in general.

During the $20^{\text {th }}$ century, work from hard duty to satisfy the needs of survival gradually turned into a way of development and self-actualization. It happened for the following reasons: the majority of the population was engaged in hired labor; work and profession became the axis of human existence, determining the position in a society, income, lifestyle, social circle, etc.; the changes lead to the formation of a special employment democracy, employment values; people started to view employment as a source of property and well-being, it became the centre of economic progress.

At the same time, tireless work and its ever-increasing productivity leads to a steady decline in demand for human resources. Fewer people can produce more and more goods and services (just in the past 150 years, labor productivity has grown more than 50 times). Due to the automation of production and the development of robotics, deserted manufacturing sites are no longer surprising. According to forecasts, in the next decades, there will be an ongoing decline in manufacturing employment and it will approach the mark of 2-3\% (Frey \& Osborne, 2013). The emergence of each new, more efficient workplace destroys dozens and hundreds of old ones. Therefore, modern economic growth, based on scientific and technological progress, is "growth without jobs".

The future labor market will be characterized by such features as the development of information technology, cross-functionality, universality and mobility of employees, minimization of staffing, and the headcount reduction. Competitiveness in the labor market of the future will mean uniqueness, the customer's (employer's or directly consumer's) demand for a particular employee.

No country is yet ready for the changes that await us. Inequality in access to resources (including work) leads to social instability, and the lack of consumers in the consumer economy leads to economic instability.

Therefore, many questions arise, and socio-economic science should look for the answers to them. What is the purpose of new technologies? What are they striving for? What is the aim of a machine or artificial intelligence that can perform $60-70-80 \%$ of our work? Should people compete even harder in the labor market, work more for less? Should the income itself remain linked to employment, and should the availability of work continue to be the only way to generate income, while jobs will become completely unavailable for many people? If machines perform more and more work and do not get money for it, how is this money distributed? What does social justice mean under such conditions and how is it possible to achieve it?

In this article, we will investigate one thing among these pressing issues: how, according to which principles, basing on which system should employee compensation be organized and, more broadly, how the income of the population should be organized in the new economy, in the newest labor market? How do the compensation functions transform with such radical changes in the social and employment relations that accompany a new economy?

The overall objective of the paper is to analyze and systematize the peculiarities of labor and payment for it in the new economy, to investigate the gradual transformation of its functions, to identify the trends in changes of incomes of the population under the influence of the computerization of human life, and to substantiate the directions of agents' adaptation to these changes at different levels. 


\section{LITERATURE REVIEW}

The review of scientific literature revealed the active interest of researchers in the issues of transformation of income and wages in the transition to a new economy. Close to these problems are considered in the works of such scientists: Antoniuk (2016), Armstrong and Brown (2006), Dumanska (2015), Kolot and Herasymenko (2017), Milkovich and Newman (2010), Bilan, Mishchuk, and Dzhyhar (2017), Tsimbaliuk (2018), Henderson (2005) and others.

Mishchuk and Dzhyhar (2017) studied the interconnection between remuneration and human capital determinants basing on fuzzy logic method that shall be utilized in defining their effect upon the interest on human capital use (wages). The authors defined the determinants impossible to describe by way of quantitative indicators, i.e. gender, education level, experience. Such approach as ranked evaluations or investment cost indicators in the formation of certain human capital constituents, the use of the offered methodology for studying the link between human capital factors and remuneration allows using real characteristics of the human capital of employees. The close link between wages and human capital reproduction processes is also indicated by other authors: Bechtel (2007), Jeremic, Slovic, and Radojicic (2012), Martins and Lopes (2016), etc. The issue of fair wages is also relevant and directly related to wage functions (Kim et al., 2019).

Considering the crisis phenomena in the economy of Ukraine, in the field of remuneration, Ukrainian authors, first of all, pay attention to the fact that under current conditions, the salary does not fulfil its functions, does not form an effective demand for goods and services, does not ensure social justice.

The rapid and multi-vector processes taking place in the social and employment sphere in the new economy were investigated in the papers by Bell (1973), Wallerstein (2004), Castel (2002), Kolot and Kravchuk (2015), Liashenko and Vyshnevskyi (2018) and others.

Regarding to the transition to a new economy, our society faces with different aspects of digital technologies implementation. The seriousness of these issues shows the eight editions of "The 2017 State
New Economy Index: Benchmarking Economic Transformation in the States" that were published in 1999, 2002, 2007, 2008, 2010, 2012, 2014 and 2017. The newest edition was developed by Atkinson and $\mathrm{Wu}$ (2017). The interconnection between changes in labor sphere and digital transformation describes blocks of new indicators: knowledge jobs (indicators assess the employment of IT specialists outside the IT sphere; jobs held by managers, experts, and technicians; the education of labor force; immigration of knowledge workers; migration of domestic knowledge workers; worker productivity in the industrial sector; and employment in high-wage traded services), innovation capacity (indicators evaluate the number of jobs in high-tech industries such as electronics production, telecommunications, and biomedical industries; the number of scientists and engineers in the labor force).

Various aspects of the work and payment in the digital economy are presented in a study by Valenduc and Vendramin (2016). The authors studied the various aspects of absolutely new features found in the digital economy model; major cases of technological shift observable in the working environment; new forms of work in the digital economy; distance and employment relationships; problems entailed in regulating a labor world shortage of its customary structures. Fuchs and Fisher (2015) explore digital labor theory of value, proposing theoretical and empirical study that contributes to our understanding of Marx's labor theory of value. The peculiarities of labor in the new economy are also presented in studies by Huws (2016), Meil (2015) and also in reports of the World Economic Forum $(2016,2018)$. In the Future of Jobs Report 2018, the authors highlight four drivers of change: omnipresent high-speed mobile internet, artificial intelligence, far-reaching adoption of big data analytics, and cloud technology that are set to dominate the period 2018-2022 as drivers positively affecting business growth. The spread of information technologies leads to changes of the employment types: about $50 \%$ of companies expect that automation will lead to some shortage in their full-time labor force by 2022, based on the job profiles of their personnel base today.

Yet, the above-mentioned fundamental theoretical issues of remuneration and ensuring productive employment for the general population in a new economy require an in-depth study. 


\section{METHODOLOGY}

In order to achieve the objective, the authors used common scientific and special research techniques, in particular: analysis and synthesis, systematization and generalization, analytical grouping method for characterizing salary functions, as well as changes in the social and labor sphere that take place in the new economy, correlation-regression analysis to determine the relationship between average income and factors affecting its level.

The research is based on the supposition that in the digital economy, the rate of total incomes of workers is much less dependent on the amount of time spent at the main place of work than in the "traditional" economy. To do this, we have conducted a study on the interconnection between the average income and the factors affecting it in individual EU member states and Ukraine.

Nowadays, with the development and spread of information and communication technologies, gig employment is becoming increasingly widespread. The spread of online gig work - paid work allocated and performed by way of internet platforms without an explicit or implicit contract for continuing employment - is seen as a relatively widespread phenomenon among economic development specialists, and the world's largest global development network is promoting its potential to foster human development (United Nations Development Programme, 2015). At their core, online gig work platforms act as a matchmaking service. They coordinate buyers and sellers of short-term contract work, regulating the personalized, short-term relationship between buyers and sellers in a similar manner to traditional labor intermediaries. "Online gig work" itself refers to casual work that is performed and delivered via internet platforms. In this environment, workers undertake a number of more or less concurrent tasks rather than having one job role. For example, a job on an internet gig work platform could exist in the form of a temporary graphic design project, which itself might refer to an array of Photoshop tasks. These tasks could be any number of various things, including more routine tasks such as data entry (Graham et al., 2017).
Significant shifts in the world labor market and the spread of gig employment is also evidenced by the dynamics of the Online Labour Index (Kassi \& Lehdonvirta, 2016). Online Labour Index assesses the usage of online labor across countries and occupations by tracking the number of projects and tasks placed on internet gig platforms in near-real time.

As of December 2018 compared to December 2016, Online Labour Index increased by 19.6 percentage points, in some periods, it was 139.8 (May 2017). It should be noted that the index is standardized so that 100 index points on the y-axis show the everyday average number of new projects in May 2016 (iLabour Project, 2018). This indicates significant changes in the global labor market that must be considered now.

Based on the current realities of the "digital world" and the trends in the further expansion of digital employment as the main factors that affect the level of incomes of a modern worker, we determine: the number of hours worked in full-time employment in a week, average length of training, social transfers. The study uses an array of data on the dynamics of these indicators in individual $\mathrm{EU}$ member states (Eurostat, 2018) and similar data for Ukraine (State Statistics Service of Ukraine, 2018). We carried out an assessment of the relationship between average income and the factors affecting it in separate EU member states and Ukraine in the statistical analysis system Statistica 10.

\section{PRESENTATION OF THE MAIN MATERIAL}

\subsection{Features of employment and organization of employee compensation in traditional and new economy}

In traditional economy and economic science, wages and salaries are regarded as the income derived from human labor, which a hired employee receives because of implementing his/her work ability, and which should ensure the objectively necessary reproduction of the workforce. For the 
enterprise, they are an element of the cost of production included in the cost of products, works (services), and, at the same time, the main factor in ensuring the material interest of employees in achieving the final labor results.

While investigating labor remuneration in the new conditions of information society, we need to distinguish between the peculiarities of employment and the organization of employee compensation in traditional and new economies (see Table 1).

Table 1. Features of employment and organization of employee compensation in traditional and new economy

Source: Developed by the authors.

\begin{tabular}{|c|c|c|}
\hline Feature & $\begin{array}{l}\text { Traditional } \\
\text { economy }\end{array}$ & New economy \\
\hline Nature of labor & $\begin{array}{l}\text { Routine work } \\
\text { with a small } \\
\text { share of creative } \\
\text { components }\end{array}$ & Creative, innovative work \\
\hline $\begin{array}{l}\text { Productive } \\
\text { labor power }\end{array}$ & $\begin{array}{l}\text { It is determined } \\
\text { by equipment } \\
\text { capacity }\end{array}$ & $\begin{array}{l}\text { It is determined primarily } \\
\text { by the development and } \\
\text { application of information } \\
\text { and communication } \\
\text { technologies }\end{array}$ \\
\hline $\begin{array}{l}\text { Organization of } \\
\text { work }\end{array}$ & $\begin{array}{l}\text { Prevalence of } \\
\text { occupations } \\
\text { requiring direct } \\
\text { presence in the } \\
\text { workplace }\end{array}$ & $\begin{array}{l}\text { Spread of jobs with } \\
\text { flexible hours and } \\
\text { distance employment }\end{array}$ \\
\hline $\begin{array}{l}\text { Learning } \\
\text { and working } \\
\text { opportunities }\end{array}$ & $\begin{array}{l}\text { They are limited by } \\
\text { local educational } \\
\text { institutions and } \\
\text { employers }\end{array}$ & $\begin{array}{l}\text { The opportunities to } \\
\text { study and work remotely } \\
\text { through the Internet are } \\
\text { extremely wide }\end{array}$ \\
\hline $\begin{array}{l}\text { Labor values of } \\
\text { employees }\end{array}$ & $\begin{array}{l}\text { Stable employment, } \\
\text { permanent } \\
\text { employment, } \\
\text { compensation } \\
\text { growth with long } \\
\text { service benefits }\end{array}$ & $\begin{array}{l}\text { Innovative content and } \\
\text { the nature of work, } \\
\text { encouraging ingenuity, } \\
\text { creativity and uniqueness }\end{array}$ \\
\hline $\begin{array}{l}\text { Rewards } \\
\text { program }\end{array}$ & $\begin{array}{l}\text { They are } \\
\text { standard for most } \\
\text { employees }\end{array}$ & $\begin{array}{l}\text { They are personalised, } \\
\text { flexible, aimed at } \\
\text { attracting, motivating and } \\
\text { developing talents }\end{array}$ \\
\hline $\begin{array}{l}\text { Frequency of } \\
\text { remuneration } \\
\text { (benefits) } \\
\text { review }\end{array}$ & $\begin{array}{l}\text { As a rule, once a } \\
\text { year }\end{array}$ & $\begin{array}{l}\text { Depending on the results } \\
\text { of a particular project }\end{array}$ \\
\hline
\end{tabular}

Dynamic changes in the social and employment sphere outline new requirements for employees, in particular the need to adapt quickly to the conditions of changing environment, to study constantly. Training becomes a kind of lifestyle for an ever-increasing number of employees. In the near future, due to an ever-increasing growth in the flexibility of the labor market, the notion of traditional, standard employment will disappear. This also applies to the flexibility of working time, flexibility of salaries and wages, and processes for the formation of total labor income.

\subsection{Salary and wage functions in traditional and new economy}

At the same time, we cannot argue that, in modern conditions, there are revolutionary changes in the social and employment sphere. These, albeit very deep transformations that take place are, rather, evolutionary, as they are a natural consequence of social development - technological, economic, social progress, which has acquired special, inherent features with the advent of computer and the development of global internet. Brintseva (2016) states that each of the economies - pre-industrial, industrial, post-industrial, new - faced the appearance and then gradual spread and change of new types of labor: from physical to creative one, therefore, processes of transformation of human capital took place simultaneously (p. 48).

Considering the transformation of the classical functions of salaries and wages in the context of the transition to a new economy, it is necessary to distinguish the following distinctive features (see Table 2).

In the new economy, the reproductive function of wages/salaries is decreasing to a certain extent, since the provision of employees and their family members with the necessary vital goods takes place from many sources of income, and does not directly depend on compensation received at one permanent workplace (as for the absolute majority of the population in the industrial economy). Given the volatile nature of employment, employee participation in many projects at the same time and the spread of distance employment, the work according to temporary employment contracts is becoming widespread. State regulation of income in the new economy becomes much more complex, it becomes internationally important and should be carried out at the world labor market with the active participation of leading international organizations and facilitate the provision of minimum social standards for the whole population (regardless of participation in the employment market). 
Table 2. Salary and wage functions in traditional and new economy

Source: Compiled by the authors.

\begin{tabular}{|c|c|c|}
\hline Functions & Traditional economy & New economy \\
\hline $\begin{array}{l}\text { Reproductive } \\
\text { function }\end{array}$ & $\begin{array}{l}\text { The function lies in providing workers and } \\
\text { members of their families with the necessary } \\
\text { vital goods for the restoration of labor force, for } \\
\text { the reproduction of generations. This function is } \\
\text { closely linked to the peculiarities of state wage/ } \\
\text { salary regulation, with the establishment of } \\
\text { such minimum national living wage that would } \\
\text { ensure the reproduction of the workforce. }\end{array}$ & $\begin{array}{l}\text { Due to the temporary nature of employment, the } \\
\text { participation of the employee in many projects and the } \\
\text { spread of non-typical employment, the reproductive function } \\
\text { of wages and salaries diminishes to some extent. Providing } \\
\text { workers with life benefits comes from many sources of } \\
\text { income, and it doesn't depend on the level of compensation } \\
\text { in one workplace. State regulation of wages and salaries in the } \\
\text { new economy is transformed into state regulation of incomes } \\
\text { in general and the prevention of poverty. }\end{array}$ \\
\hline Stimulating function & $\begin{array}{l}\text { This function lies in establishing the dependence } \\
\text { between the size of the salary/wage with the } \\
\text { quantity and quality of labor of a particular } \\
\text { employee, his/her labor contribution to the } \\
\text { results of the company. This dependence should } \\
\text { be of such scale as to encourage continuous } \\
\text { improvement of the results of the work. }\end{array}$ & $\begin{array}{l}\text { Stimulating function of wages/salaries gradually becomes a } \\
\text { stimulating function of employment in general. In case of non- } \\
\text { standard employment, only the actual result is determined } \\
\text { by the level of income. Wages/salaries lose their role as the } \\
\text { most important stimulus of labor. Labor values also undergo } \\
\text { significant transformations. The determinants are the } \\
\text { content of work, its innovation, the creativity of tasks, the } \\
\text { harmonization of work and personal life. }\end{array}$ \\
\hline $\begin{array}{l}\text { Regulatory or } \\
\text { resource allocation } \\
\text { function }\end{array}$ & $\begin{array}{l}\text { This function lies in optimizing the allocation } \\
\text { of labor force by region, branch, enterprise, } \\
\text { taking into account the market situation. Higher } \\
\text { salaries at more cost-effective workplaces } \\
\text { stimulate workers to leave inefficient jobs. }\end{array}$ & $\begin{array}{l}\text { Optimization of the placement of employees takes place } \\
\text { remotely in the global information space. Ensuring productive } \\
\text { employment is becoming global. Even with regard to those } \\
\text { works that employees do not currently perform remotely, this } \\
\text { function is expanding to an international level and becomes a } \\
\text { major factor in labor migration. }\end{array}$ \\
\hline Social function & $\begin{array}{l}\text { The social significance of this function is to } \\
\text { ensure social justice, firstly, in the distribution } \\
\text { of income between hired employees and } \\
\text { employers, and, secondly, in the distribution } \\
\text { between hired employees themselves according } \\
\text { to the results of labor input. }\end{array}$ & $\begin{array}{l}\text { In the new economy, social functions are performed not by } \\
\text { wages/salaries, but by the basic unconditional income, the } \\
\text { availability of vocational education and the opportunity to } \\
\text { attract start-up capital. } \\
\text { Social justice is determined by the distribution of goods } \\
\text { created by works and other technical means of production. }\end{array}$ \\
\hline Optimizing function & $\begin{array}{l}\text { Wages/salaries as a component of production } \\
\text { costs are a factor in motivating an entrepreneur } \\
\text { to rationally use labor, constantly increase its } \\
\text { productivity by improving material, technical, } \\
\text { economic, and socio-economic issues. }\end{array}$ & $\begin{array}{l}\text { The optimizing function lies at the heart of the entire } \\
\text { remuneration process in the new economy, because } \\
\text { technological development, the introduction of digital } \\
\text { technologies ensures almost limitless opportunities for } \\
\text { increasing productivity and reducing working time in favour } \\
\text { of flexible schedule. Flexible productive employment } \\
\text { opportunities, their optimization in the global space are } \\
\text { important driving forces of human development. }\end{array}$ \\
\hline $\begin{array}{l}\text { Formation of effective } \\
\text { demand of the } \\
\text { population }\end{array}$ & $\begin{array}{l}\text { Its purpose is to reconcile effective demand, } \\
\text { on the one hand, and the production of } \\
\text { consumer goods, on the other hand. Since } \\
\text { effective demand is formed under the influence } \\
\text { of two main factors - needs and income of } \\
\text { the population, then with the help of wages/ } \\
\text { salaries, the proportions between the supply } \\
\text { and demand are established. }\end{array}$ & $\begin{array}{l}\text { This function remains very important for maintaining the } \\
\text { economic system in a market format. However, it goes beyond } \\
\text { compensation, extends to the entire system of regulation and } \\
\text { redistribution of income through social transfers and taxes. In } \\
\text { order to preserve the incentives for economic development } \\
\text { and society, a small share of people should not concentrate } \\
\text { the majority of income. Moreover, the development itself } \\
\text { should be considered, first of all, in the non-economic sense, } \\
\text { and the whole system of valuables should change. }\end{array}$ \\
\hline
\end{tabular}

The introduction of unconditional basic income that has already begun in many countries around the world partly helps to implement the reproductive function of wages/salary, the problem of ensuring social stability and equity through providing livelihoods for the general population, expanding opportunities for self-realization and the most productive use of labor potential.

For the first time, in 1795, Thomas Paine developed the idea of universal (or unconditional) basic income. He proposed paying all British 21-year-olds a $\mathfrak{E} 15$ grant and $\mathfrak{E} 10$ per annum to those over 50. Marutyan (2017) states that Paine believed such an approach to be a fair way of combating poverty and inequality of income. Nevertheless, the implementation of the concept of unconditional basic income (also known as guaranteed minimum income) took place much later. One of the first experiments was conducted in the US and Canada in 1970s-1980s. Therefore, in the USA in the 1970s-1980s, there were four experiments, lasting from 3 to 5 years. Unconditional basic income was $\$ 1,000-2,000$ 
per month. In Canada, in the mid-1970s, there also was one experiment that lasted 5 years. In this case, the unconditional basic income was $\$ 16,989$ per year for one person $(\$ 24,027$ per year for a couple). Nowadays, the implementation of this concept is most intense in the EU countries - Italy, Finland, the Netherlands, but covers a small proportion of citizens of these countries. At this stage, the main goal is to determine how the unconditional basic income affects the lives of people in the study group: do their opportunities to receive education increase (and have they taken advantage of them), have they opened their own business or changed their work to the one that brings them more pleasure? It is obvious that in case of spending these funds for entertainment, bad habits, etc., the experiment will not be considered successful, since unconditional basic income should contribute to the expansion of human development opportunities, it should give a person an opportunity to be a decent human being, to move from existence to life by overcoming the poor living conditions and nutrition.

In addition to the introduction of basic unconditional income in its various interpretations, there are other successful practices of ensuring social stability and reducing inequality. An interesting model is Norway, which implements the concept of responsible use of natural resources - gas and oil, which have been found and started to be mined relatively recently in the 1970s. An important decision for future generations of Norwegians was to send all revenues from the extraction of gas and oil into a special fund, which, in the future, when the natural resources are exhausted, should ensure stable revenue to the state budget.

Belkova (2016) states that the fund was established in 1990 with the purpose of improving the economy and avoiding dependence on changes in energy prices. Nowadays, Norway spends no more than $4 \%$ of the total fund on domestic needs.

The United Arab Emirates is also an example of the use of natural wealth for the benefit of the people. This policy most accurately reflects the words of Sheikh Zayed who was the first presi- dent of the UAE: "If Allah the Almighty has favoured us with wealth, our first commitment is to seek Allah's satisfaction and to express our gratitude to Him by utilizing this wealth to make this country better and to bring goodness to its people. The most precious wealth of the country is its people, whom we must take care of well. There is no use for money without men". In UAE, a foreign investor does not pay taxes; instead, s/he gives $51 \%$ of his business to a local citizen. The authorities give the investor a candidate for the business partner according to the list. All local Arabs, and there are approximately 1 million of them out of 9 million Arab residents of the Emirates, each year receive the so-called oil percentage. Pidluzhna (2018) underlines that Sheikh Zayed once said that oil was not found under his feet, but on the ground where his people live, so every local resident has the right to it.

The stimulating function of wages/salaries in the new economy is also undergoing significant changes. On the one hand, if employees work in different project teams, only the actual result determines the level of their income. On the other hand, employee compensation is not the only, or even the most important, labor incentive. New generations of workers have other labor values. For them, the determinative is the content of work, its innovative nature, and the creativity of the tasks to be solved. Thus, for generation $\mathrm{Z}$, work is not a goal of life, but just one of many its aspects. Therefore, the possible balance between work and personal life, flexible schedule is a very important aspect of working life for modern employees. Generation $\mathrm{Z}$ is integrated into the digital environment, it is a part of it. Work in the digital economy, the transfer of the work in the online environment contributes to the integration of work in the life of a modern person. And this fact, of course, also contributes to the further digitalization of the economy.

The regulatory function of wages/salary is realized in a different way with the help of modern information and communication technologies and activation of labor migration. Optimization of the placement of employees takes place in the global information space and changing the 
place of work does not necessarily mean changing the place of actual residence. Growth in productivity already has a global nature and can be considered as a socio-economic phenomenon of world dimension. With regard to those works that employees do not currently perform remotely (medical, cosmetic services, education, day care, etc.), this function is expanding to an international level and becomes a major factor in labor migration.

It is worth noting that according to the $\mathrm{UN}$, we witness the world's largest population movements across the international borders over the past 70 years. In 2000-2016, the number of international migrants has increased by $49 \%$ and there are approximately 258 million people. The benefits of migration far outweigh its costs, but in the public consciousness, the negative perception of migrants prevails, which often affects the policies pursued by the states. According to UN News (2017), in 2017, the volume of transfers sent by migrants to their homeland amounted to 429 billion dollars.

Thus, the regulatory function of remuneration under current conditions also plays the role of regulating (increasing) the incomes of poorer countries.

Changes in the implementation of the social function of wages/salary are primarily due to the fact that in order to create an ever-increasing share of production in the new economy, no expensive means of production concentrated with a limited number of owners are needed. The products acquire a non-tangible form; the distribution channels are global. Not only access to means of production, but also the presence of unique knowledge, skills and ability to implement them, determine the level of income of employees, their labor contribution to the process of production of information products and services.

In addition, it should be emphasized that in the new economy, social functions are performed not by wages/salaries, but by the basic unconditional income, the availability of vocational education and the opportunity to attract startup capital as the main social elevators. In the robotized, informative new economy, social justice has to be spoken of in terms of how goods that are created by works and other technical means of production will be distributed.

Artificial intelligence is gradually replacing workers who are engaged in non-highly intellectual work. This is primarily a feature of the banking sector, trade, administrative services, etc.

The optimizing function is the basis of the entire remuneration process in the new economy, because globalization, rapid technological development, the introduction of digital technologies in all spheres of life open virtually limitless opportunities for increasing productivity, cheapening and increasing production. At the same time, a responsible approach to employment regulation offers broad opportunities for shortening working hours and more useful, efficient spending of free time in favor of human development.

If we consider the digitalization process from the point of view of dividing the economy into three sectors (primary sector - agriculture and mining, secondary one - industrial production, and tertiary one - services), then the fundamental distinction is not so much an increase in the share of the tertiary sector or the emergence and expansion of a new one (digital economy), but a radical transformation of all three existing sectors. Given the current technological opportunities and trends in their development, the classical division between these sectors may totally disappear. For instance, it is now technologically possible to remotely manage agricultural land, harvest, produce industrial products, carry out medical operations and provide various services in the smart mode (online). Consequently, according to Liashenko and Vyshnevskyi (2018), there is a digitalization of not separate sectors of the economy, but the entire economic system (pp. 8-9). In this context, the gradual reduction of human participation in the production process, reducing the number of jobs is an important challenge for the world community. The right response to these challenges should be to reduce working hours and increase the time to study, improve health and spiritual development in people's lives. 
However, we should note that the process of transition to a new economy in Ukraine is not only gradual, but also very uneven. For some types of economic activity, it takes place more rapidly and progressively (IT sphere, consulting, etc.); these processes are dynamic in international companies that promote the dissemination of progressive business solutions, information and communication technologies in the domestic economic space. Modern employees in Ukraine face with many challenges in an unstable social, economic and political environment. Therefore, expanding opportunities for productive employment and competitive labor remuneration are important vectors that can really be a driving force behind positive change and contribute to expanding human development opportunities for the general population.

In the new economy, the function of forming an effective population's demand requires special attention. If robotization results are concentrated in small population strata, then with the decrease in aggregate demand, the incentives for the development of the economy as a whole will be undermined. Introduction of unconditional income is the easiest way to keep effective demand of the population in the absence of jobs due to robotizing. However, we should also seek for other means of reducing social inequality, including those that are already widespread in developing countries. First and the foremost, this is a progressive tax on all types of income, which is a clear and steady human responsibility, and which is not tied to official work and "transparent" salary (as it is now in Ukraine). It is also important to calculate a progressive tax basing on the size of the family and income per family member. With a real shortage of jobs, it is worth looking at the length of the working week, because it is much safer for a society to have a population who is busy on a shorter working day than having the crowds of the unemployed. Apart from that, by increasing productivity in shorter working hours, the owner can produce more benefits than before, and without reducing the compensation of hired employees.

In order to maintain effective demand as the basis of the economy, management at all levels should gradually move away from so-called 'economocentric' viewpoint, focused exclusively on the accumulation of as much material wealth as possible, and the receipt of excess profits. The world, for the sake of self-preservation, has to turn to other, non-economic, benchmarks of progress.

The fact that the processes of globalization are gradually taking place is evidenced by the results of an international study "Human Capital Trends 2018" conducted by Deloitte (2018). Thus, society increasingly expects business to fulfil the principle of social responsibility and participation in solving important social issues. It is this principle that should become the basis for the company's image and mission. $77 \%$ of the interviewed respondents called social responsibility an important or very important business component. According to the Millennial Survey 2017 conducted by Deloitte (2017), 76\% of respondents believe that business is a force that can positively affect the society. Despite the connection between the social impact and financial performance of the company, only $18 \%$ of respondents regard social responsibility as the main priority of the corporate strategy. $34 \%$ of companies do not have enough social program or such program lack financing, and $22 \%$ do not pay attention to it at all.

\subsection{Transformation trends in the field of income and salary in the transition to a new economy in the EU member states and Ukraine}

In order to identify and assess the transformation trends in the field of incomes and employee compensation in the transition to a new economy, we examined the interconnections and dynamics of the average income and the main factors influencing it (working time, average duration of training and social transfers) in the EU member states and in Ukraine.

The distribution of annual income in the Eurozone is rather uneven so the income in the "richest" and "poorest" countries can vary 10-20 times. In Ukraine, we determined this indicator, taking into account the average annual euro rate for the 
Table 3. Dynamics of average income in EU member states and Ukraine in 2008-2016, Euro per year

\begin{tabular}{|c|c|c|c|c|c|c|c|c|c|}
\hline \multirow{2}{*}{ Country } & \multicolumn{9}{|c|}{ Year } \\
\hline & 2008 & 2009 & 2010 & 2011 & 2012 & 2013 & 2014 & 2015 & 2016 \\
\hline Belgium & 17,985 & 19,313 & 19,464 & 20,008 & 20,280 & 21,483 & 21,705 & 21,654 & 22,295 \\
\hline Bulgaria & 2,171 & 2,828 & 3,017 & 2,914 & 2,860 & 2,924 & 3,311 & 3,332 & 3,151 \\
\hline Czech Republic & 6,068 & 7,295 & 7,058 & 7,451 & 7,791 & 7,694 & 7,622 & 7,423 & 7,838 \\
\hline Denmark & 24,161 & 25,029 & 25,668 & 26,944 & 27,184 & 27,444 & 27,861 & 28,364 & 28,665 \\
\hline Germany & 18,309 & 18,586 & 18,797 & 19,043 & 19,595 & 19,582 & 19,733 & 20,668 & 21,275 \\
\hline Estonia & 5,547 & 6,209 & 5,727 & 5,598 & 5,987 & 6,579 & 7,217 & 7,889 & 8,645 \\
\hline Ireland & 22,995 & 22,445 & 20,512 & 19,726 & 19,748 & 19,856 & 20,169 & 21,688 & 22,407 \\
\hline Greece & 10,800 & 11,496 & 11,963 & 10,985 & 9,513 & 8,371 & 7,680 & 7,520 & 7,500 \\
\hline Spain & 13,966 & 14,795 & 14,605 & 13,929 & 13,868 & 13,524 & 13,269 & 13,352 & 13,681 \\
\hline France & 18,899 & 19,644 & 19,960 & 19,995 & 20,603 & 20,924 & 21,199 & 21,415 & 21,713 \\
\hline Croatia & - & - & 5,810 & 5,579 & 5,377 & 5,078 & 5,225 & 5,453 & 5,726 \\
\hline Italy & 15,640 & 15,605 & 15,964 & 15,971 & 15,979 & 15,733 & 15,759 & 15,846 & 16,247 \\
\hline Cyprus & 16,024 & 16,451 & 16,180 & 16,990 & 16,927 & 15,873 & 14,400 & 13,793 & 14,020 \\
\hline Latvia & 4,740 & 5,355 & 4,488 & 4,195 & 4,450 & 4,666 & 5,203 & 5,828 & 6,365 \\
\hline Lithuania & 4,111 & 4,715 & 4,030 & 3,857 & 4,337 & 4,698 & 4,823 & 5,180 & 5,645 \\
\hline Luxembourg & 30,917 & 31,764 & 32,333 & 32,538 & 32,779 & 33,301 & 34,320 & 35,270 & 33,818 \\
\hline Hungary & 4,400 & 4,739 & 4,241 & 4,493 & 4,696 & 4,449 & 4,512 & 4,556 & 4,768 \\
\hline Malta & 10,009 & 10,503 & 10,435 & 10,862 & 11,449 & 12,093 & 12,787 & 13,493 & 13,572 \\
\hline The Netherlands & 19,522 & 20,156 & 20,292 & 20,310 & 20,562 & 20,839 & 20,891 & 21,292 & 22,733 \\
\hline Austria & 19,413 & 20,469 & 21,058 & 21,463 & 21,807 & 22,073 & 23,211 & 23,260 & 23,694 \\
\hline Poland & 4,155 & 5,097 & 4,405 & 5,025 & 5,060 & 5,164 & 5,336 & 5,556 & 5,884 \\
\hline Portugal & 8,143 & 8,282 & 8,678 & 8,410 & 8,323 & 8,177 & 8,229 & 8,435 & 8,782 \\
\hline Romania & 1,952 & 2,172 & 2,036 & 2,091 & 2,049 & 2,016 & 2,155 & 2,315 & 2,448 \\
\hline Slovenia & 10,893 & 11,864 & 11,736 & 11,999 & 12,122 & 11,852 & 11,909 & 12,332 & 12,327 \\
\hline Slovakia & 4,792 & 5,671 & 6,117 & 6,306 & 6,927 & 6,737 & 6,809 & 6,930 & 6,951 \\
\hline Finland & 19,794 & 20,962 & 21,349 & 21,826 & 22,699 & 23,272 & 23,702 & 23,763 & 23,650 \\
\hline Sweden & 20,217 & 20,477 & 18,897 & 21,584 & 23,852 & 25,401 & 25,838 & 25,306 & 25,164 \\
\hline UK & 18,923 & 16,262 & 17,106 & 17,136 & 19,166 & 18,694 & 20,528 & 21,028 & 21,136 \\
\hline Iceland & 32,206 & 22,362 & 18,320 & 18,973 & 19,361 & 21,234 & 22,487 & 24,554 & 28,379 \\
\hline Norway & 31,798 & 33,737 & 32,399 & 36,453 & 40,106 & 42,909 & 43,775 & 41,483 & 39,573 \\
\hline Switzerland & 26,987 & 28,958 & 30,666 & 33,936 & 39,407 & 40,791 & 38,162 & 39,586 & 44,253 \\
\hline Turkey & 2,903 & 3,049 & 2,754 & 3,326 & 3,222 & 3,438 & 3,497 & 3,386 & - \\
\hline Ukraine & 2,374 & 1,797 & 2,284 & 2,474 & 3,123 & 3,217 & 2,134 & 1,675 & 1,651 \\
\hline
\end{tabular}

relevant year; the rapid drop in the course of the national currency in crisis years had a negative effect on the dynamics of average annual incomes (see Table 3).

The variation in the hours worked per week of fulltime employment is significantly lower than among EU member states, but its dynamics in 2008-2016 indicates a gradual decrease in the number of hours worked against the rising incomes. The average length of training varies considerably more: from 10.9 years in Italy to 19.0 years in Iceland in 2016. Social transfers have a significant place in the structure of incomes in Ukraine (more than 1/3 of aggregate income), which significantly differentiates the country from the EU member states, where this indicator in 2008-2016 was in the range from $0.3 \%$ to $31.4 \%$ (and with an average of $12.9 \%$ ). We determined the strength of a relationship between the average income and the factors affecting it in the EU and Ukraine on the basis of a correlation-regression analysis (see Table 4). 
Table 4. Relationship between average income and the factors affecting it in individual EU member states and Ukraine

Source: Calculated by the authors according to the data in Eurostat (2018) State Statistics Service of Ukraine $(2017,2018)$, United Nations Development Programme (2018), National Bank of Ukraine (2018).

\begin{tabular}{|c|c|c|c|}
\hline Country & $\begin{array}{c}\text { Hours worked } \\
\text { per week } \\
\text { of full-time } \\
\text { employment }\end{array}$ & $\begin{array}{l}\text { Average } \\
\text { length of } \\
\text { training }\end{array}$ & $\begin{array}{c}\text { Social } \\
\text { transfers }\end{array}$ \\
\hline Belgium & $0.804 * * * *$ & $0.948 * * * * *$ & $0.888 * * * *$ \\
\hline Bulgaria & $-0.762 * * * *$ & $0.817 * * * *$ & $0.608^{* * *}$ \\
\hline Czech Republic & $-0.775 * * * *$ & $-0.814^{* * * *}$ & $0.561^{* * *}$ \\
\hline Denmark & $0.134^{*}$ & $-0.050^{*}$ & $-0.370 * *$ \\
\hline Germany & $-0.808 * * * *$ & $0.868 * * * *$ & $0.594 * * *$ \\
\hline Estonia & $-0.807 * * * *$ & $0.588 * * *$ & $-0.538 * * *$ \\
\hline Ireland & $0.100^{*}$ & $-0.664 * * *$ & $-0.589 * * *$ \\
\hline Greece & $-0.876^{* * * *}$ & $-0.824 * * * *$ & $-0.654^{* * *}$ \\
\hline Spain & $0.421^{* *}$ & $-0.782 * * * *$ & $-0.722 * * * *$ \\
\hline France & $-0.806^{* * * *}$ & $0.965^{* * * * *}$ & $0.849 * * * *$ \\
\hline Croatia & $0.383 * *$ & $-0.455^{* *}$ & $-0.075^{*}$ \\
\hline Italy & $-0.407 * * *$ & $0.392 * *$ & $0.612 * * *$ \\
\hline Cyprus & $-0.511 * * *$ & $-0.537^{* * *}$ & $-0.555^{* * *}$ \\
\hline Latvia & $-0.068^{*}$ & $-0.253^{*}$ & $-0.195^{*}$ \\
\hline Lithuania & $-0.261^{*}$ & $0.733^{* * * *}$ & $-0.783^{* * * *}$ \\
\hline Luxembourg & $0.623 * * *$ & $0.718 * * * *$ & $0.681^{* * * *}$ \\
\hline Hungary & $0.017^{*}$ & $-0.040 *$ & $-0.253^{*}$ \\
\hline Malta & $0.258 *$ & $0.191 *$ & $0.498 * *$ \\
\hline $\begin{array}{l}\text { The } \\
\text { Netherlands }\end{array}$ & $0.205^{*}$ & $0.637^{* * *}$ & $0.536 * * *$ \\
\hline Austria & $-0.984 * * * * *$ & $0.925^{* * * * *}$ & $0.922 * * * * *$ \\
\hline Portugal & $-0.280^{*}$ & $0.115^{*}$ & $0.279 *$ \\
\hline Romania & $-0.652 * * *$ & $-0.370 * *$ & $0.599 * * *$ \\
\hline Slovenia & $-0.919 * * * * *$ & $0.287^{*}$ & $0.759 * * * *$ \\
\hline Slovakia & $0.458^{*}$ & $0.661^{* * *}$ & $0.759 * * * *$ \\
\hline Finland & $-0.856^{* * * *}$ & $0.463 * *$ & $0.869 * * * *$ \\
\hline
\end{tabular}

\begin{tabular}{l|c:c|c}
\hline Country & $\begin{array}{c}\text { Hours worked } \\
\text { per week } \\
\text { of full-time } \\
\text { employment }\end{array}$ & $\begin{array}{c}\text { Average } \\
\text { length of } \\
\text { training }\end{array}$ & $\begin{array}{c}\text { Social } \\
\text { transfers }\end{array}$ \\
\hline Sweden & $-0.826^{* * * *}$ & $0.326^{* *}$ & $0.857^{* * * *}$ \\
\hline UK & $0.500^{* * *}$ & $0.341^{*}$ & $0.618^{* * *}$ \\
\hline Iceland & $0.907^{* * * * *}$ & $-0.190^{*}$ & $-0.480^{* *}$ \\
\hline Norway & $-0.384^{* *}$ & $0.746^{* * * *}$ & $0.804^{* * * *}$ \\
\hline Switzerland & $0.426^{* *}$ & $0.935^{* * * * *}$ & $0.955^{* * * * *}$ \\
\hline Turkey & $-0.804^{* * * *}$ & $0.856^{* * * *}$ & $0.172^{*}$ \\
\hline Poland & $-0.747^{* * * *}$ & $0.808^{* * * *}$ & $0.895^{* * * *}$ \\
\hline Ukraine & $0.000^{*}$ & $0.000^{*}$ & $0.963^{* * * * *}$ \\
\hline
\end{tabular}

Notes: Relationship strength according to the correlation coefficient $*$ - weak $(0.10-0.29), * *$ - moderate $(0.30-0.49)$, $* * *$ - significant $(0.50-0.69), * * * *$ - strong $(0.70-0.89)$ $* * * * *$ - very strong $(0.90-0.99)$. " + " - the relationship is direct, "-" - the relationship is inverse.

The results of the conducted analysis are the most important part, they indicate that under present conditions, the cumulative income does not depend on the time spent at the primary place of employment. Wages, salaries and traditional employment gradually lose their fundamental importance in the life of a modern person in the era of digital technology. The income sources are gradually being diversified. The paper revealed a rather interesting trend: the increase in the length of training in the system of classical formal education no longer guarantees high incomes throughout life (in some countries within the study, the relationship between the length of training and income is even inverse). We observed the strongest impact of social transfers on incomes of the population in Ukraine, Switzerland, Austria, Belgium, Finland and France.

\section{CONCLUSION}

In the paper, we obtained empirical results that confirm the abovementioned theoretical hypotheses about the dynamic changes in the social and employment sphere and society in general; and the world community as a whole, the public administration of each individual country and every real or potential employee in particular have to prepare for it carefully. The changes in the social and employment sphere, associated with the spread of processes and phenomena, briefly summarized by the phrase "new economy", require an in-depth research from the side of science, as well as increased attention from the managers at all levels - from personal to global one.

The social and employment sphere undergo the following major changes:

- $\quad$ rapid growth of productivity;

- rapid change in the labor market demand with its general decline;

- change in the forms and systems of labor organization towards increasing flexibility and instability; 
- corresponding change in the main functions and forms of remuneration towards individualization, contract basis, dependence on the outcome;

- transformation of the value system of modern employees and the loss of salary's positions as the foremost motivator of hired employment;

- differentiation of the income system, increasing the role of social transfers in the absence of jobs;

- changing requirements for vocational education in terms of its specialisation, intensification, accessibility and mobility as the main social elevator in an era of change;

- further globalization and increasingly active redistribution of all resources around the world, including intellectual human capital.

Such radical transformations affect the lives of each person, opening up new opportunities and, at the same time, putting forward new threats. The global community as a whole, every single society, state, enterprise, every person must prepare themselves for such changes, because they simply cannot avoid them.

The study revealed a significant transformation of all wage functions in the transition to a new economy.

The reproductive function of wages diminishes to some extent, since wages cease to be the only source of income for most people through the introduction of unconditional basic income and other means of reducing inequality. Income regulation should be carried out with the active participation of international organizations and promote the provision of social standards for the general population.

The stimulating function of wages in the new economy turns into a stimulating function of employment in general. Labor values are transformed substantially. The determinants are the content of work, its innovation, the creativity of tasks, the harmonization of work and personal life, and wages lose the role of the most important stimulus of labor.

The regulating function of wages is differently realized in the new economy. The placement of workers is regulated in the international space by means of distance employment and migration, and this becomes the basis of global growth of labor productivity, increase of incomes of the population of poorer countries.

Social functions in the new economy are performed not by wages, but by the basic unconditional income, the availability of vocational education, the opportunity to attract start-up capital, and therefore the social function of wages is weakened.

The optimization function is fundamental in the wage process in the new economy, which opens up many options for improving productivity and increasing production. Optimization also manifests itself in reducing the number of jobs. The response to this should be to reduce working hours and increase the time for human development.

Formation of solvent demand of the population in the new economy is a special challenge, the answer to which should be the introduction of unconditional income and progressive tax on all types of income (in terms of income per member of the family) as a steady responsibility of human.

In such conditions, fair employee compensation and ensuring productive employment is a challenge not only of the national, but also of international scale. Prospective directions of reducing inequality and 
social tension in society is the guarantee of the unconditional basic income, progressive tax on all types of income, reduction of the length of working time while maintaining payments and improving productivity. In addition to avoiding social dangers, it would be a proactive progressive function of expanding human development opportunities.

\section{REFERENCES}

1. Antoniuk, V. P. (2016). Соціальна політика у сфері оплати праці: проблеми та шляхи забезпечення ії гідного рівня (на прикладі промисловості) [Sotsialna polityka u sferi oplaty pratsi: problemy ta shliakhy zabezpechennia yii hidnoho rivnia (na prykladi promyslovosti)]. Retrieved from http:// dspace.nbuv.gov.ua/bitstream/ handle/123456789/127391/1Antonyuk.pdf?sequence $=1$

2. Armstrong, M., \& Brown, D. (2006). Strategic Reward: Making It Happen. London: Kogan Page.

3. Atkinson, R., \& Wu, J. (2017). The 2017 State New Economy Index: Benchmarking Economic Transformation in the States. http://dx.doi. org/10.2139/ssrn.3066923

4. Bechtel, R. (2007). Calculating human capital: the market based valuation of the human resource. German Journal of Human Resource Management: Zeitschrift für Personalforschung, 21(3), 206-231. Retrieved from https://journals.sagepub.com/doi/ abs/10.1177/239700220702100302

5. Belkova, O. (2016). Как распоряжаться ресурсами страны. Onыт Норвегии [Kak rasporyazhatsya resursami strany. Opyt Norvegii]. Retrieved from https://nv.ua/ukr/opinion/belkova/chomu-ukrajina-mozhe-navchitisja-u-norvegiji-258434.html

6. Bell, D. (1973). The Coming of Post-Industrial Society: A Venture in Social Forecasting. New York: Basic Books.

7. Bilan, Yu., Mishchuk, H., \& Dzhyhar, T. (2017). Human capital factors and remuneration: analysis of relations, modelling of influence. Business: theory and practice, 18 , 208-214. Retrieved from https:// btp.press.vgtu.lt/article/13003/
8. Brintseva, O. H. (2016). Трансформація людського капіталу в контексті зміни змісту праці в новій економіці [Transformatsiia ludskoho kapitalu v konteksti zminy zmistu pratsi $\mathrm{v}$ novii ekonomitsi]. Ukraine: aspects of labor, 3-4, 46-49.

9. Castel, R. (2002). The Metamorphosis of the Social Question. A Chronicle of Wage Labor. Konstanz: University Publishers.

10. Deloitte (2017). The Deloitte Millennial Survey 2017. Apprehensive millennials: seeking stability and opportunities in an uncertain world. Retrieved from https:// www2.deloitte.com/global/en/ pages/about-deloitte/articles/millennialsurvey.html?id=gx:2el:3pr:h ctrends18:eng:cons:040318

11. Deloitte (2018). Human capital trends. Retrieved from https:// www2.deloitte.com/content/dam/ Deloitte/at/Documents/humancapital/at-2018-deloitte-humancapital-trends.pdf

12. Dumanska, V. (2015). Оплата праці: українські проблеми на тлі світових тенденцій [Oplata pratsi: ukrainski problemy na tli svitovykh tendentsii]. Ukraine: Aspects of Labor, 2, 35-40. Retrieved from http://www.irbis-nbuv.gov. ua/cgi-bin/irbis_nbuv/cgiirbis_64. exe?I21DBN=LINK\&P21DBN= UJRN \&Z21ID $=\& S 21 \mathrm{REF}=10 \& S$ $21 \mathrm{CNR}=20 \& S 21 \mathrm{STN}=1 \& \mathrm{~S} 21 \mathrm{FM}$ $\mathrm{T}=\mathrm{ASP} \_$meta $\& \mathrm{C} 21 \mathrm{COM}=\mathrm{S} \& 2$ S21P03=FILA $=\& 2$ S21STR=Uap_2015_2_8

13. Eurostat (2018). Hours worked per week of full-time employment. Retrieved from https://ec.europa. eu/eurostat/tgm/table.do?tab=tab le\&init $=1$ \&language $=\mathrm{en} \& \mathrm{pcode}=\mathrm{t}$ ps00071\&plugin $=1$

14. Eurostat (2018). Mean and median income before social transfers (pen- sions included in social transfers) by household type. Retrieved from http://appsso.eurostat.ec.europa. $\mathrm{eu} /$ nui/show.do?dataset=ilc_ di13b\&lang=en

15. Eurostat (2018). Mean and median income by age and sex - EU-SILC survey [ilc_di03]. Retrieved from http://appsso.eurostat.ec.europa. eu/nui/show.do?dataset=ilc di03\&lang=en

16. Frey, C. B., \& Osborne, M. A. (2013). The future of employment: how susceptible are jobs to computerisation. Retrieved from https://www.oxfordmartin.ox.ac. uk/downloads/academic/The_Future_of_Employment.pdf

17. Fuchs, C., \& Fisher, E. (Eds.) (2015). Reconsidering value and labor in the digital age, Dynamics of virtual work series. Basingstoke, Palgrave Macmillan.

18. Graham, M., Lehdonvirta, V., Wood, A., Barnard, H., Hjorth, I., \& Simon, D. P. (2017). The Risks and Rewards of Online Gig Work at The Global Margins. Oxford: Oxford Internet Institute. Retrieved from https://www.oii.ox.ac.uk/ publications/gigwork.pdf

19. Henderson, R. I. (Ed.) (2005). Compensation Management in a Knowledge-Based World (576 p.) (10th ed.). Pearson.

20. Huws, U. (2016). Logged in. The new economy makes it harder than ever to untangle capitalism from our daily lives. Jacobin. Retrieved from https://www. jacobinmag.com/2016/01/huwssharing-economy-crowdsourceprecarity-uber-workers/

21. Jeremic, V., Slovic, D., \& Radojicic, Z. (2012). Measuring human capital: a statistical approach. Actual Problems of Economics, 5, 359-363.

22. Kässi, O., \& Lehdonvirta, V. (2016). Online Labour Index: 
Measuring the Online Gig Economy for Policy and Research. Retrieved from https://mpra.ub.unimuenchen.de/86627/8/MPRA_paper_86627.pdf

23. Kim, T.-Y., Wang, J., Chen, T., Zhu, Y., \& Sun, R. (2019). Equal or equitable pay? Individual differences in pay fairness perceptions. Human Resource Management, 58, 169-186. https://onlinelibrary. wiley.com/doi/pdf/\%2010.1002/ hrm.21944

24. Kolot, A. M., \& Herasymenko, О. (2017). Глобальна соціальна нерівність доходів: природа, тенденції, наслідки [Hlobalna sotsialna nerivnist dokhodiv: pryroda, tendentsii, naslidky]. Sotsialno-trudovi vidnosyny: teoriia ta praktyka, 2, 8-47. Retrieved from http://ir.kneu.edu.ua/bitstream/2010/22582/3/8-47.pdf

25. Kolot, A. M., \& Kravchuk, O. I. (2015). Людина і нова економіка: діалектика розвитку [Liudyna i nova ekonomika: dialektyka rozvytku]. Sotsialno-trudovi vidnosyny: teoriia ta praktyka, 1(9), 8-29. Retrieved from http:// www.irbis-nbuv.gov.ua/cgi-bin/ irbis_nbuv/cgiirbis_64.exe?I21 DBN=LINK\&P21DBN=UJRN $\& Z 21 \mathrm{ID}=\& S 21 \mathrm{REF}=10 \& S 21 \mathrm{C}$ $\mathrm{NR}=20 \& S 21 \mathrm{STN}=1 \& \mathrm{~S} 21 \mathrm{FMT}$ $=\mathrm{ASP} \_$meta\&C $21 \mathrm{COM}=\mathrm{S} \& 2$ $\mathrm{S} 21 \mathrm{P} 03=\mathrm{FILA}=\& 2$ S21STR=stvttp_2015_1_3

26. Liashenko, V. I., \& Vyshnevskyi, O. S. (2018). Цифрова модернізація економіки України як можливість проривного розвитку [Tsyfrova modernizatsiia ekonomiky Ukrainy yak mozhlyvist proryvnoho rozvytku]. National Academy of Sciences of Ukraine, Institute of Industrial Economics.

27. Martins, M., \& Lopes, I. (2016). Intellectual capital and profitability: a firm value approach in the European companies. Verslas teorija ir praktika, 17(3), 234242. Retrieved from https:// www.researchgate.net/publication/309098223_Intellectual_Capital_and_Profitability_A_Firm_ Value_Approach_in_the_European_Companies
28. Marutyan, R. (2017). Безумовний базовий дохід - утопія чи панацея? [Bеzumovnyi bazovyi dokhid - utopiia chy panatseia?] Retrieved from https://matrixinfo.com/wp-content/cache/ all/2017/11/15/bezumovnyjbazovyj-dohid-utopiya-chy-panatseya//index.html

29. Meil, P. (2015). ICT and work. Future opportunities, fresh insecurities. Paper presented at the Eurofound Conference "Changing Working Conditions in Europe: Moving towards better work, First findings from the Eurofound's 6th European Working Conditions Survey", November 24, Luxembourg.

30. Milkovich, G. T., \& Newman, J. M. (2010). Compensation (10th ed.). McGraw-Hill/Irwin.

31. National Bank of Ukraine (2018). Official exchange rate of hryvnia against foreign currencies. Retrieved from https://bank.gov.ua/ files/Exchange_r.xls

32. Pidluzhna, Yu. (2018). У скупого шейха гроші з'їи мури, а мудрий шейх роздав їх людям... [U skupoho sheikha hroshi zily shchury, a mudryi sheikh rozdav yikh liudiam ...]. Retrieved from https://wz.lviv.ua/article/363592u-skupogo-shejkha-groshi-z-jilishchuri-a-mudrij-shejkh-rozdavjikh-lyudyam

33. State Statistics Service of Ukraine (2017). Statistical Yearbook of Ukraine for 2016 (edited by I. E Werner). Kyiv.

34. State Statistics Service of Ukraine (2018). Доходи та витрати населення України [Dokhody ta vytraty naselennia Ukrainy]. Retrieved from http://www.ukrstat. gov.ua/operativ/operativ2007/gdn/ dvn_ric/dvn_ric_u/arh_dvn_kv_u. htm

35. State Statistics Service of Ukraine (2018). People. Retrieved from http://www.ukrstat.gov.ua/operativ/operativ2007/ds/nas_rik/ nas_u/nas_rik_u.html

36. World Economic Forum (2016). The Future of Jobs Report 2016. Insight Report. Retrieved from http://www3.weforum.org/docs/ WEF_Future_of_Jobs.pdf
37. World Economic Forum (2018). The Future of Jobs Report 2018. Insight Report. Retrieved from http://www3.weforum.org/docs/ WEF_Future_of_Jobs_2018.pdf

38. The iLabour Project (2018). The Online Labour Index. Retrieved from http://ilabour.oii.ox.ac.uk/ online-labour-index/

39. Tsimbalyuk, S.O. (2018). Indicators for estimating remuneration policy in relation to implementation of the principles of decent work. Retrieved from http://ir.kneu.edu.ua/bitstream/2010/25846/1/5_Tsymbaliuk.pdf

40. UN News (2017). UN urges international cooperation to make migration safer in a world on the move. Retrieved from https://news. un.org/en/story/2017/12/639732un-urges-international-cooperation-make-migration-safer-worldmove\#.Wj19lt9l_IU

41. United Nations Development Programme (2018). Human Development Data (1990-2015). Retrieved from http://hdr.undp.org/en/data

42. United Nations Development Programme (2015). Human Development Report 2015. New York.

43. Valenduc, G., \& Vendramin, P. (2016). Work in the digital economy: sorting the old from the new (Working papers - European Trade-Union Institute (ETUI), 03).

44. Wallerstein, I. (2004). Конеи знакомого мира: социология XXI века [Konets znakomoho mira: sotsiologiya XXI veka]. Moscow: Logos. 